\title{
Role of Injection Depo Medoroxy Progesterone Acetate in the Management of Abnormal Uterine Bleeding in Norplant User
}

\author{
Mahfuz Ara Begum', Begum Aminun Nahar ${ }^{2}$, Monowara Sultana ${ }^{3}$, Md. Amjad Ali ${ }^{4}$
}

\begin{abstract}
Background \& objective: This prospective study was undertaken to determine the role of Depomedroxy progesterone acetate (DMPA) in the management of abnormal uterine bleeding associated with norplant use.

Methods: The study was carried out in the Department of Family Planning Model Clinic of Sir Salimullah Medical College and Mitford Hospital, Dhaka between June, 2003 to December, 2005. A total 54 clients were consecutively selected, based on predefined enrolment criteria.

Results: Over two-thirds (70.6\%) of the patients were multipara (2-3 live births), 22\% primipara and the rest $7.4 \%$ grand-multipara ( 4 or more live births). Among 54 cases, $45(84 \%$ ) responded to treatment. Of the 9 $(16 \%)$ cases who failed to respond to DMPA treatment, 4 cases were given $2^{\text {nd }}$ dose of DMPA. Three cases dropped out after failing the $1^{\text {st }}$ dose and 2 cases refused to receive $2^{\text {nd }}$ dose and their norplant was removed on request. Abnormal per vaginal $(\mathrm{P} / \mathrm{V})$ bleeding began from the $1^{\text {st }}$ month of insertion of Norplant with 15 $(27.7 \%)$ cases in the $1^{\text {st }}$ month, $7(12 \%)$ cases between $2^{\text {nd }}$ to $5^{\text {th }}$ months, $16(28 \%)$ cases between $6-12$ months, $11(20 \%)$ between 13-24 months and 5 (9.3\%) cases between 25-36 months.

Conclusion: The study showed that DMPA is a simple and effective modality of treatment for women with abnormal or irregular uterine bleeding associated with norplant implant use. With increased compliance from clients' perspective, it could be a good option for treatment of women with abnormal or irregular uterine bleeding caused by norplant implant.
\end{abstract}

Key words: Injection Depo Medoroxy progesterone acetate, abnormal uiterine bleeding, Norplant etc.

\section{INTRODUCTION:}

Norplant has been extensively used contraceptive agent throughout the world. It's a new delivery system in which small amount of levonorgestrol is released for a prolonged period. Norplant- 6 releases $50-80 \mathrm{mcg}$ of Levonorgestrol per day in the $1^{\text {st }}$ year and the level falls to approximately 30 mcg per day in the succeeding 4 years. ${ }^{1}$ All the reports on its introduction and use in different countries and settings have shown that $20-30 \%$ of norplant implant users experience irregular, unpredictable uterine bleeding. ${ }^{2-6}$

Irregular bleeding is the principal side effect associated with use of norplant. Pathophysiology of irregular uterine bleeding is still unknown and its management to date has been empirical. In fact lack of effective technique for the control of irregular bleeding contributes significantly to the premature removal of norplant. It appears from a review of literature that oestrogen, progesterone

\section{Authors' information:}

'Dr. Mahfuz Ara Begum, MBBS, MCPS, DGO, FCPS, MS (Obstetrics \& Gynaecology), Associate Professor (Obstetrics \& Gynae), Comilla Medical College, Comilla.

\footnotetext{
${ }^{2}$ Begum Aminun Nahar, MBBS, MCPS (Obstetrics \& Gynaecology), Senior Consultant, M Abdur Rahim Medical College Hospital, Dinajpur. ${ }^{3}$ Mrs. Monowara Sultana, Counselor, Family Planning Model Clinic SSMC \& Mitford Hospital, Dhaka.

${ }^{4}$ Dr. Md. Amjad Ali, MS (Orthopedic), Consultant, Department of Orthopedic, Bangladesh Modernized Hospital, Mohammadpur, Dhaka, Ex Consultant NITOR, Dhaka
} 
and non-steroidal anti-inflammatory agents may reduce the number of bleeding days or active bleeding in women using norplant. However, no studies have yet documented a drop in haemoglobin concentration in norplant user. In fact converse is found-haemoglobin concentration rise in norplant user. ${ }^{7}$ Uterine bleeding or spotting more than 5-6 days is more nuisances rather than a problem of medical significance interfering personal life and hygiene of the norplant users. There are two studies to reduce the days of uterine bleeding induced by norplant use. One study ${ }^{8}$ used ethinyloestradiol $50 \mathrm{mcg} /$ day for 20 days to treat norplant induced uterine bleeding. There were no statistically significant reductions of uterine bleeding between estrogen and placebo user. Another prospective study ${ }^{9}$ compared ethinyl oestradiol alone with ethinyl oestradiol plus levonorgestrol (combination pill and a placebo). Bleeding and spotting were stopped soon with combined oral contraceptive than Ethinyl oestradiol alone. ${ }^{9}$ However, oestrogen can't be tolerated by some women who usually choose norplant. In the present study we used high dose progesterone treatment by using injection DMPA $150 \mathrm{mg}$ to stop bleeding with no oestrogenic side effect or intolerance.

\section{METHODS:}

This prospective study was carried out at Family Planning Model Clinic Sir Salimullah Medical College and Mitford Hospital (SSMC \& Mitford Hospital) between June 2003 to December 2005. During the period total number of Norplant insertion ( 6 stick for 5 years) cases were 574 . Before insertion of norplant all criteria of insertion were fulfilled e.g. explanation, exclusion of pregnancy, exclusion of any irregular $\mathrm{p} / \mathrm{v}$ bleeding. Among 574 clients 54 reported development of irregular uterine bleeding in the form of spotting $>10$ days or excessive P/V bleeding $>7$ days and were included in the study for intervention with DMPA. Pill treatment failure cases also included in the study. The clients enrolled in the study by giving voluntary consent were divided into two groups. One group $(n=29)$ was treated with Inj. DMPA (Depomedroxy progesterone acetate), while the other group $(n=25)$ was treated with Inj. DMPA after failed treatment with combined OCP (Ethinyl Estradiol plus Levonorgestrol), a contraceptive pill which is available in the family planning department of our country.

Inj. DMPA 1 ampoule (150 mg) was given I/M to each client with abnormal uterine bleeding (study population) provided there was no contraindication. The clients were advised to attend the follow up visit after 7-14 days and then at monthly intervals. Detailed evaluation was done in each visit. The evaluation parameters were duration of $\mathrm{P} / \mathrm{V}$ bleeding, any recurrence during study period, number of doses required to control the bleeding.

\begin{tabular}{|lcc|}
\hline TABLE I. Age distribution of the clients $(\mathbf{n}=\mathbf{5 4})$ \\
\hline Age (yrs) & Frequency & Percentage \\
\hline $22-25$ & 20 & 37.0 \\
$26-32$ & 30 & 56.0 \\
$33-39$ & 4 & 7.0 \\
\hline
\end{tabular}

TABLE II. Distribution of the clients by parity $(n=54)$

\begin{tabular}{lcc} 
Parity & Frequency & Percentage \\
\hline Primipara & 12 & 22.0 \\
Multipara ( 2-3 live-births) & 38 & 70.6 \\
Geandmultipara ( $\geq 4$ live birth) & 4 & 7.4
\end{tabular}

TABLE III. Time of onset of abnormal P/V bleeding after insertion of norplant $(n=54)$

$\begin{array}{lcc}\text { Time } & \text { Frequency } & \text { Percentage } \\ 1^{\text {st }} \text { month } & 15 & 27.7 \\ \text { 2-5 month } & 7 & 12.0 \\ \text { 6-12 month } & 16 & 28.0 \\ \text { 13-24 month } & 11 & 20.0 \\ \text { 25-36 month } & 5 & 9.3\end{array}$

TABLE IV. Distribution of patients by treatment outcome

$\begin{array}{lcc}\text { Response related variables } & \text { Frequency } & \text { Percentage } \\ \begin{array}{l}\text { Response to treatment }(\mathbf{n}=54) \\ \text { Responder }\end{array} & 45 & 83.3 \\ \text { Non-responder } & 9 & 16.7 \\ \text { Dose of DMPA needed }(\mathbf{n}=45) & & \\ \text { One injection } & 30 & 66.7 \\ \text { Two injection } & 15 & 33.3\end{array}$




\section{RESULTS:}

Over half ( $55 \%)$ of the patients was $26-32$ years, $37 \%$ 22-25 years, 7\% 33-39 years old (Table I). Over two-thirds (70.6\%) were multipara (2-3 live birth), $22 \%$ primipara and the rest $7.4 \%$ grand-multipara (4 or more live births) (Table II). Abnormal per vaginal $(P / V)$ bleeding started from the $1^{\text {st }}$ month of insertion of Norplant. Fifteen cases $(27.7 \%)$ exhibited $\mathrm{P} / \mathrm{V}$ bleeding in the $1^{\text {st }}$ month, $7(12 \%)$ cases between $2^{\text {nd }}$ to $5^{\text {th }}$ months $16(28 \%)$ between $6-12$ months, $11(20 \%)$ between 13-24 months and 5(9.3\%) cases between 25-36 months (Table III). Among 54 cases, 45(84\%) responded to treatment by cessation of abnormal uterine bleeding. Of the 45 responders, 15 needed 2 injections with median interval between the injections being 2 months (range: 1 month- 2 years). Of the $9(16 \%)$ cases who failed to respond to DMPA treatment, 4 failed even after $2^{\text {nd }}$ dose of DMPA. Three cases dropped out after failing the $1^{\text {st }}$ dose and 2 cases refused to receive $2^{\text {nd }}$ dose and their norplant was removed on request (Table IV).

\section{DISCUSSION:}

The Norplant sub-dermal implant is a new contraceptive option already accepted by over a million women in the United States alone and by similar number in the rest of the world. There are many advantages of using norplant, but the inherent problem of irregular bleeding resulting from continuous administration of low dose of progesterone makes it cumbersome to continue.

The incidence of abnormal P/V bleeding following norplant insertion was $9.4 \%$ (54 out of 574) which is lower compared to other similar studies conducted elsewhere (20-30\%).2,3 Participants in this trial came to the clinic because of complaints of prolonged or irregular bleeding. In the present study a substantial proportion (84\%) of the clients responded to treatment with DMPA and most $(66.7 \%)$ of the cases required only one dose and the rest required 2 doses. Only 9 cases failed to respond to treatment. There is limited study with Depo-medroxy progesterone acetate in the treatment of irregular uterine bleeding associated with norplant use. However, one study by Arias et al ${ }^{10}$ with DMPA showed changes in irregular and abnormal bleeding during month three of norplant use to amenorrhoea during month four. The treatment with DMPA doesn't alter the underlying pathophysiological process contributing to uterine bleeding/spotting episodes. Two trials ${ }^{9,11}$ (by Archer et al \& Alvarez-Sanchez et al)- one used oestradiol alone and the other Ethinyl oestradiol with Levonorgestrol showed the decrease of acute episodes of bleeding in norplant users.

\section{CONCLUSION:}

The study showed that DMPA may be a simple and effective modality of treatment for women with abnormal or irregular uterine bleeding associated with norplant implant use. Although our data are not enough to conclude the use of DMPA in the treatment of irregular or acute episodes of bleeding, physician should counsel the patient on the advantage of DMPA, i.e. dose convenience and minimum side effect. Counseling should emphasize the potential occurrence of irregular bleeding after treatment. A definitive answer awaits on further large-scale study, which could result in improvement of bleeding episodes in norplant users.

\section{REFERENCES:}

1. Ratnam SS, Rao KB, Diaz AS. Hormonal contraceptiveandcurrent problem and development. Obstetrics and Gynecology for Postgraduates, Madras; orient Longman Limited 1982;1:286-92.

2. Du MK,Zhers HM, Chen HC, chow LP. study of Norplant implant in Shanghais. Three year experience. Int J Gynecological \& obstet 1990;33:345-57.

3. Akhter H, Dunson TR, Amatya RN, Begum K, Chowdhury T, Dighe N, Krueger SL, Rahman S. A five-year clinical evaluation of NORPLANTR contraceptive subdermal implants in Bangladeshi acceptors. Contraception 1993;47:569-692.

4. Gerber S, WestnoffcLopez M,Gordant.Useof Norplant Implant in a New York City Clinic Population. Contraception 1994;49:557-64.

5. Gu SJ, Du MK, Zhang LD, Liu YL, Wang SH, Sivin I. A 5-year evaluation of NORPLANT contraceptive implants in China. Obstetrics And Gynecology 1944;83:673-78. 
6. Pasquale SA, Knuppel RA, Owens G, Bachman GA Irregular bleeding body mass index and coital frequency in Norplant contraception user. Contraception 1994; 50:109-16.

7. Sivin I. contraception with Norplant implant. Hum Repord 1994;9:1818-26.

8. Díaz S, Croxatto HB, Pavez M, Belhadj H, Stern J, Sivin I. Clinical assessment of treatments for prolonged bleeding in users of Norplant implants. Contraception 1990;42(1):97-109.

9. Alvarez-Sanchez F, Brache V, Thevenin F, Cochon L, Faundes A. Hormonal treatment for bleeding irregularities in Norplant implant users. Am J Obstet Gynecol 1996;174(3):919-22.
10. Arias RD, Jain JK, Brucker C, Ross D, Ray A. Changes in bleeding patterns with depot medroxyprogesterone acetate subcutaneous injection $104 \mathrm{mg}$. Contraception $2006 ; 74(3): 234-8$.

11. Archer DF, Philput CA, Weber ME. Management of irregular uterine bleeding and spotting associated with Norplant. Hum Reprod 1996;11(Suppl 2):24-30. 